\title{
Balanced cytokine-producing pattern in mice immunized with an avirulent Trypanosoma cruzi
}

\author{
MiLENA B. P. SOARES ${ }^{1,2}$, RENATA GONÇALVES ${ }^{1}$, ALEXANDRE S. PYRRHO ${ }^{1,3}$, \\ DEISE A. $\operatorname{COSTA}^{1}$, CLAUdIA N. PAIVA ${ }^{1}$ and CERLI R. GATTASS ${ }^{1}$ \\ ${ }^{1}$ Programa de Imunobiologia, Instituto de Biofísica Carlos Chagas Filho, UFRJ, Rio de Janeiro, RJ, Brasil \\ ${ }^{2}$ Centro de Pesquisas Gonçalo Moniz, FIOCRUZ, Salvador, BA, Brasil \\ ${ }^{3}$ Departamento de Análises Clínicas e Toxicológicas da Faculdade de Farmácia, UFRJ, RJ, Brasil \\ Manuscript received on December 18, 2002; accepted for publication on March 7, 2003; \\ presented by RICARDO GATTASS
}

\begin{abstract}
We have previously demonstrated that inoculation of BALB/c mice with trypomastigotes of CL-14, an avirulent Trypanosoma cruzi clone, prevents the development of parasitemia and mortality after challenge with virulent CL strain. In this report, we investigated the cytokine and antibody profiles induced by inoculation with CL-14 clone. Groups of mice were inoculated with trypomastigotes of CL-14 clone and challenged with infective CL strain. Challenged CL-14-inoculated mice had lower levels of IFN- $\gamma$ and higher production of IgG1 antibodies as compared to CL strain-infected mice. Previous inoculation with CL-14 clone partially prevented the suppression of IL-2 production caused by CL strain infection. No significant differences were found regarding IL-4 production by splenocytes from CL-14-inoculated or control groups after challenge with CL-strain. Our results show that protection against acute $T$. cruzi infection induced by CL-14 inoculation correlates with a balanced T1/T2 cytokine production, a profile likely to be beneficial for the host.
\end{abstract}

Key words: Trypanosoma cruzi, protection, cytokines, humoral response.

\section{INTRODUCTION}

Cytokines are soluble mediators which regulate and act as effector mechanisms of immunity. They are critical factors in driving the establishment of protective or exacerbating responses against a variety of pathogens. In an attempt to identify the profile of a protective response against Trypanosoma cruzi, the etiologic agent of Chagas' disease, several studies have been carried on the production of cytokines by different mouse strains upon infection (DosReis 1997). While the presence of IFN- $\gamma$ and IL-4 in the supernatants from lymphoid cell cultures was associated with resistance and susceptibility, respec-

Correspondence to: M.B.P. Soares

E-mail: milena@cpqgm.fiocruz.br tively (Hoft et al. 1993), in situ analysis showed no such correlation (Zhang and Tarleton 1996). Moreover, both susceptible and resistant mice produced similar levels of IFN- $\gamma$ (Zhang and Tarleton 1996), suggesting the involvement of other factors in the control of infection.

Despite the lack of association between T1/T2 phenotypes and resistance of some particular mouse strains against $T$. cruzi infection, IFN- $\gamma$ is known to participate in the control of the acute phase parasitemia. Administration of exogenous IFN- $\gamma$ increases resistance (Reed 1988), while treatment with anti-IFN- $\gamma$ antibodies renders the mice more sensitive to infection (Torrico et al. 1991). In fact, IFN- $\gamma$ activates macrophages to produce nitric ox- 
ide and destroy T. cruzi in vitro (Gazzinelli et al. 1992), whereas the lack of either IFN- $\gamma$ receptor or iNOS expression renders mice highly susceptible to T. cruzi infection (Hölscher et al. 1998). The polarization towards a Th1 profile has also been described in mice protected against $T$. cruzi by immunization with T. cruzi proteins (Miller et al. 1996, Rodrigues et al. 1999, Schnapp et al. 2002). In order to understand the mechanisms of protective immunity against $T$. cruzi, we studied a model of inoculation with trypomastigotes of the CL-14 avirulent clone, derived from the CL strain of T. cruzi (Lima et al. 1991). Mice inoculated with live trypomastigote forms of the CL-14 clone show complete absence of parasitemia or pathology, and develop an efficient immunity against a lethal challenge with virulent parasites (Lima et al. 1991, 1995). Here we studied the cytokine profile and the production of anti-T. cruzi antibodies that help to keep CL-14inoculated mice protected against virulent $T$. cruzi.

\section{MATERIALS AND METHODS}

$\mathrm{BALB} / \mathrm{c}$ mice (6-8 weeks of age) were used in all experiments. CL-14 is a T. cruzi clone isolated from the CL strain. CL-14 trypomastigotes were obtained by in vitro metacyclogenesis and purified by DEAEchromatography, as described elsewhere (Lima et al. 1991). Inoculation with clone CL-14 was performed by injecting $10^{7}$ live purified trypomastigotes i.p. in $0.2 \mathrm{ml}$ of phosphate-buffered saline (PBS). The original CL strain was maintained by serial blood passages through $\mathrm{BALB} / \mathrm{c}$ mice. Infections were performed by intraperitoneal (i.p.) inoculation of contaminated blood containing $10^{4}$ trypomastigotes.

Splenocytes from mice sacrificed at different time points (see figure legends) were plated in 24 well plates $\left(5 \times 10^{6} /\right.$ well $)$ in $1 \mathrm{ml}$ of RPMI supplemented with $0.5 \%$ normal mouse serum, $2 \mathrm{mM} \mathrm{L-}$ glutamine, and $5 \times 10^{-5} \mathrm{M}$ 2-mercaptoethanol (Life Technologies, GIBCO-BRL, Gaithersburg, MD). Cultures were stimulated with $1 \mu \mathrm{g}$ of Concanavalin A (Con A; Sigma, St. Louis, MO) for 24 or 48 hours at $37^{\circ} \mathrm{C}$ and $5 \% \mathrm{CO}_{2}$. Cell-free supernatants were then collected and stored at $-20^{\circ} \mathrm{C}$ for cy- tokine detection by ELISA technique, using capture and detection antibodies purchased from PharMingen (San Diego, CA), according to the manufacturer's instructions. Samples of plasma were tested for IFN- $\gamma$ production, whereas supernatants were tested for IL-2, IL-4 and IFN- $\gamma$ production. After incubation with streptoavidin-peroxidase conjugate (Sigma), the assay was developed with OPD substrate (o-phenylenediamine-dihydrochloride, Sigma) and stopped with HCL $3 \mathrm{~N}$. The plate was then read at $570 \mathrm{~nm}$ in a Benchmark microplate reader Bio-Rad (Richmond, CA) Benchmark. Curve regression was performed with the help of Microplate Manager software (Bio Rad).

Anti-T.cruzi isotype production was evaluated by ELISA assays. Briefly, ELISA plates were coated with $T$. cruzi antigen (prepared by freezeand-thawing $\mathrm{CL}$ strain epimastigote suspensions) overnight at $4{ }^{\circ} \mathrm{C}$. After washing plates, $50 \mu$ l of diluted plasma samples (1/20-1/12500, duplicate) were incubated for $8 \mathrm{~h}$ at $4^{\circ} \mathrm{C}$. Plates were then washed with PBS-0.05\% Tween 20 and incubated with isotype-specific anti-mouse IgG1 and IgG2a conjugated to alkaline phosphatase (Southern Biotechnology Associates, Birmingham, AL) to reveal bound antibodies. After washing, assays were developed with p-NPP (Zymed, San Francisco, CA) and read under a $410 \mathrm{~nm}$ filter in a microplate reader.

All experimental procedures were conducted in accordance with guidelines for care and use of laboratory animals (CAUAP) of the Institute of Biophysics Carlos Chagas Filho, which conform to the National Institutes of Health (Bethesda, MD, USA) guidelines.

\section{RESULTS AND DISCUSSION}

To evaluate the production of cytokines by the protective response induced by CL-14 trypomastigotes, groups of mice were inoculated with the CL-14 clone and challenged with trypomastigotes of the CL strain six weeks later. Serum levels of IFN$\gamma$ and cytokine production in response to stimulation of splenocytes in vitro with Con A were evaluated two weeks after the infective challenge. 
At this timepoint, no IFN- $\gamma$ could be detected in sera from CL-14-inoculated controls (Figure 1A). Challenged-CL-14 inoculated mice had detectable, but lower serum levels of IFN- $\gamma$ than nonimmunized mice infected with the CL strain. Production of IFN- $\gamma$ after stimulation of splenocytes in vitro with Con A was similar to that described in vivo (Figure 1B). Despite the lower levels of IFN- $\gamma$ in CL-14-inoculated mice after challenge with CL strain, we cannot rule out a role of this cytokine in protection induced by CL-14 clone. T. cruzi infection induces the production of high levels of IFN- $\gamma$ during the acute phase of the disease (Hoft et al. 1993, Zhang and Tarleton 1996, our own data), possibly as a result of intense macrophage stimulation by the parasite to produce IL-12 and IL-18, two potent IFN- $\gamma$ inducing factors (Meyer zum Büschenfelde et al. 1997, Camargo et al. 1997). Since parasitemia is absent after the challenge of CL-14inoculated mice, it is possible that serum IFN- $\gamma$ levels are relatively low upon challenge as a result of parasitemia control. The production of IL-4 by stimulated splenocytes varied among experiments, but in general they were similar in the groups challengedimmunized and CL-infected (Figure 1D).

Immunosuppression is a hallmark of acute $T$. cruzi infection (DosReis 1997). Inoculation of clone CL-14 induces a moderate and transient decrease in the production of IL-2 stimulated by mitogens, while infection with the $\mathrm{CL}$ strain induces a longer and more severe decrease in this response (data not shown). Prior inoculation with clone CL-14 partially prevented the suppression of IL-2 production induced by infection with the CL strain (Figure 1C). These results parallel the prevention of the polyclonal lymphocyte activation induced by $T$. cruzi in CL-14-immunized mice (Paiva et al. 1999). It is possible that the presence of circulating antibodies in CL-14-immunized mice contribute to quickly control the antigenic burden, thereby preventing the induction of such immune abnormalities.

IFN- $\gamma$ induces IgG2a secretion by activated lymphocytes, whereas IL-4 induces a switch to IgG1 production in various models (Finkelman et al. 1990). High levels of IFN- $\gamma$ are produced during acute infection with T. cruzi. Thus, we compared the serum levels of anti-T. cruzi $\operatorname{IgG} 1$ and $\operatorname{IgG} 2$ a between normal or CL-14-inoculated mice two weeks after infective challenge with the CL strain. An increase in the serum titers of IgG1 antibodies to $T$. cruzi was observed after challenge of CL-14 inoculated mice with the CL strain (Figure 2A). These titers were far higher in mice previously inoculated with CL-14 clone than in CL-infected control mice. In contrast, the titers of T. cruzi-specific IgG2a antibodies were not significantly altered in CL-14 inoculated mice two weeks after challenge with $\mathrm{CL}$ strain (Figure 2B). The increased IgG1 production by CL-14-inoculated mice compared to CL infected mice shown here and in a previous report (Pyrrho et al. 1998) may be the result of a more balanced IFN$\gamma /$ IL-4 production elicited by CL-14 inoculation.

The role of different IgG subclasses in protection against $T$. cruzi infection has varied in studies using different models of immunization. In a model of protection induced by DNA immunization, the predominant isotype induced was IgG2a (Planelles et al. 2001), whereas, in another study, the predominant isotype found was IgG1 (Costa et al. 1998). In our model, IgG1 is also the prevalent isotype stimulated by CL-14 inoculation (Pyrrho et al., 1998) and increases considerably after challenge with CL strain. In spite of that, we cannot rule out that both IgG subclasses participate in the protection induced by this avirulent clone as various studies have shown protective roles of $\mathrm{IgG} 1$ and $\mathrm{IgG} 2$ antibodies against T. cruzi. (Brodskyn et al. 1989, Cerban et al. 1992).

This study shows that the efficient immunity induced by the T. cruzi clone CL-14 follows a T1/T2 and immunoglobulin isotype pattern different from other models of immunization described in the literature (Miller et al. 1996, Rodrigues et al. 1999). The finding of polarized $\mathrm{T} 1$ responses in other models of immunization against $T$. cruzi suggested an important role for IFN- $\gamma$ in protection. Despite its protective role in the control of the acute phase parasitemia, IFN- $\gamma$-producing T-cell responses upon $T$. cruzi infection have also been associated with sever- 
A

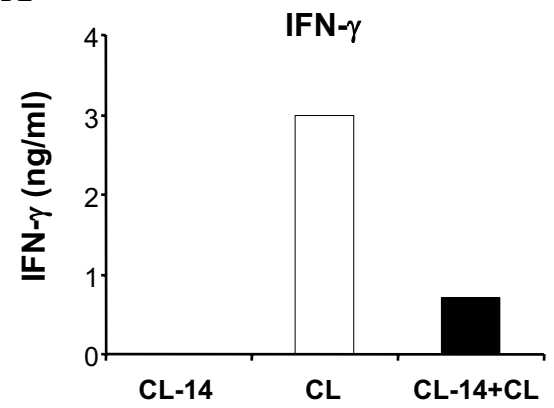

C

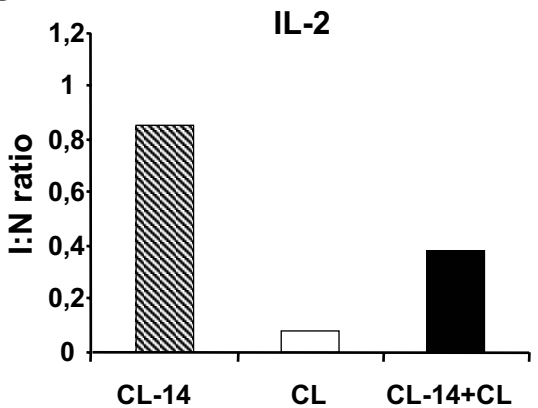

B

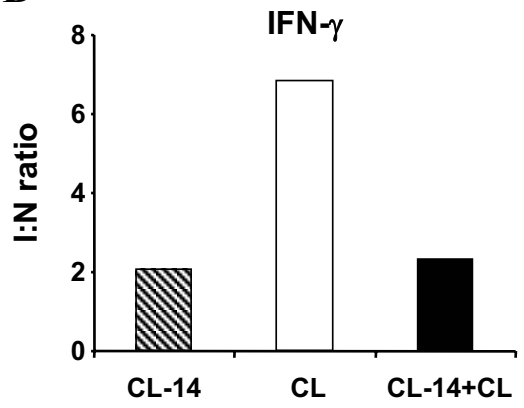

D

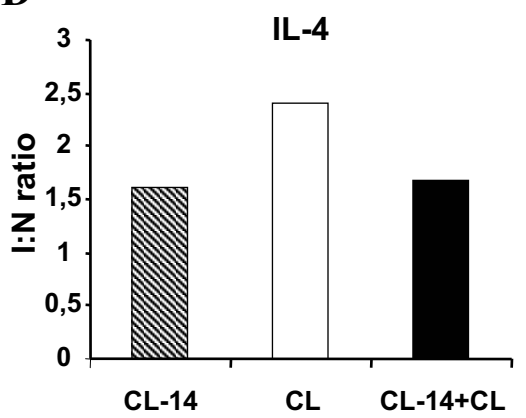

Fig. 1 - Cytokine production in mice inoculated with clone CL-14 and challenged with CL-strain trypomastigotes. Groups of BALB/c mice (non-inoculated controls or mice inoculated 6 weeks before with $10^{7}$ purified CL-14 trypomastigotes) were challenged with $10^{4} \mathrm{CL}$-strain trypomastigotes. Three mice from each group (CL-14 clone or CL strain) were sacrificed two weeks after challenge. Pools of plasma were assayed by ELISA to determine the IFN- $\gamma$ levels (A). Splenocytes were cultured in 24 well plates and stimulated with Con A $(1 \mu \mathrm{g} / \mathrm{ml})$, as described in Material and Methods. Cell-free supernatants were collected after $24 \mathrm{hs}$ of incubation and assayed to determine the IFN- $\gamma$ (B), IL-2 (C) and IL-4 (D) levels by ELISA. The data represent the ratio between cytokine levels of splenocyte cultures from T. cruzi inoculated mice $\left(10^{7}\right.$ CL-14 clone: dashed bars; CL strain: open bars; CL strain after inoculation with CL-14 clone: black bars) and the levels of splenocyte cultures from normal mice, upon stimulation with Con A. Figure shows the results of one representative experiment of three performed.

ity of chronic cardiomyopathy in mice and patients (Bahia-Oliveira et al. 1998). Moreover, IL-4 deficient BALB/c mice infected with $T$. cruzi develop early and accentuate cardiomyopathy (Soares et al. 2001). In this regard, a reduced Th1 response such as that observed in our model with clone CL-14 inoculation may be beneficial by preventing the development of inflammatory responses in the chronic phase of infection, a possibility which is currently being investigated.

\section{ACKNOWLEDGMENTS}

The authors wish to thank Drs. Antoniana Krettli and Stephen Popper for careful review of the manuscript. This work was supported by grants from the World Health Organization (WHO 960853), CNPq, PRONEX (MCT) and FAPERJ.

\section{RESUMO}

Inoculação de camundongos BALB/c com tripomastigotas do clone avirulento de Trypanosoma cruzi CL-14 protege contra o desenvolvimento de parasitemia e mortali- 
A

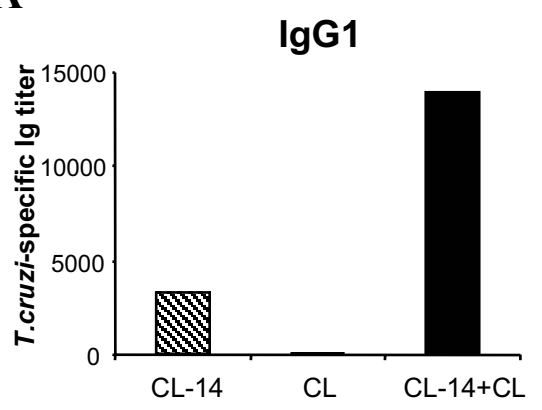

B

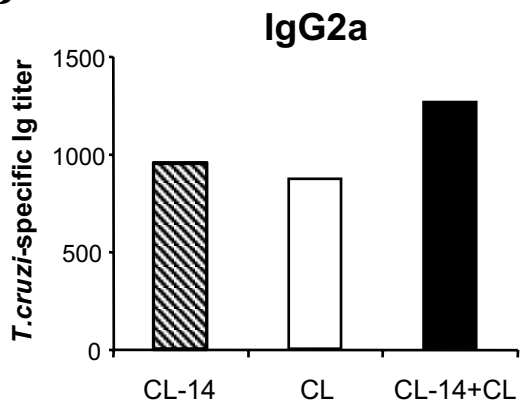

Fig. 2 - Production of IgG1 and IgG2a by mice inoculated with CL-14 clone and challenged with CL strain trypomastigotes. BALB/c mice were inoculated with 107 purified CL-14 trypomastigotes. Groups of normal littermates and CL-14-inoculated mice were challenged with $10^{4} \mathrm{CL}$ strain trypomastigotes 6 weeks later. Three mice from each group (CL or CL-14+CL) and from a group that received only the inoculation of $10^{7}$ trypomastigotes of CL-14 clone (CL-14) were bled two weeks after challenge. Pools of plasma were assayed by ELISA to determine the T. cruzi-specific IgG1 (A) and IgG2a (B) titers, as described in Materials and Methods. Similar results were obtained in two independent experiments.

dade após desafio com a cepa virulenta CL. No presente trabalho, investigamos os perfis de produção de citocinas e anticorpos induzidos por inoculação com CL-14. Grupos de camundongos foram inoculados com tripomastigotas do clone CL-14 e desafiados com a cepa CL. Camundongos inoculados com o clone CL-14 desenvolveram níveis significativamente mais baixos de IFN- $\gamma$ e níveis mais elevados de IgG1 após desafio com a cepa CL, em comparação com animais controles infectados com a cepa CL. Inoculação prévia com o clone CL-14 preveniu parcialmente a supressão da produção de IL-2 causada pela infecção por CL. Não foram observadas diferenças significativas quanto à produção de IL-4 por esplenócitos de camundongos inoculados com CL-14 ou controles, após desafio com a cepa CL. Os resultados indicam que a proteção contra a fase aguda da infecção por $T$. cruzi induzida pela inoculação com o clone CL-14 está correlacionada a um padrão de resposta T1/T2 misto, o que pode ser benéfico para o hospedeiro.

Palavras-chave: Trypanosoma cruzi, proteção, citocinas, resposta humoral.

\section{REFERENCES}

Bahia-Oliveira LM, Gomes JA, Rocha MO, Moreira MC, Lemos EM, Luz ZM, Pereira ME, Coff-
MAN RL, Dias JC, CANCADO JR, GAZZINELli G AND Correa-Oliveira R. 1998. IFN-gamma in human Chagas' disease: protection or pathology? Braz J Med Biol Res 31: 127-131.

Brodskyn CI, Silva AM, Takehara HA and Mota I. 1989. IgG subclasses responsible for immune clearance in mice infected with Trypanosoma cruzi. Immunol Cell Biol 67: 343-348.

Camargo MM, Almeida IC, Pereira MeS, Ferguson MAJ, Travassos LR and Gazzinelli RT. 1997. Glycosylphosphatidylinositol-anchored mucin-like glycoproteins isolated from Trypanosoma cruzi trypomastigotes initiate the synthesis of proinflammatory cytokines by macrophages. J Immunol 158: 5890-5901.

Cerban F, Gruppi A and Vottero-Cima E. 1992. Trypanosoma cruzi : involvement of $\mathrm{IgG}$ isotypes in parasitemia control of mice immunized with parasite exoantigens of isoeletric point 4.5. Exp Parasitol 75: 137-145.

Costa F, Franchin G, Pereira-Chioccola VL, RibeRIÃo M, SCHENKMAN S AND RodRIGUES MM. 1998. Immunization with a plasmid DNA containing the gene of trans-sialidase reduces Trypanosoma cruzi infection in mice. Vaccine 16: 768-774.

DosReis GA. 1997. Cell-mediated immunity in experi- 
mental Trypanosoma cruzi infection. Parasitol Today 13: 335-342.

Finkelman F, Homes J, Katona I, Urban J, Beckmann M, Park L, Schooley K, Coffman R, MossMAN T AND PAUl W. 1990. Lymphokine control of in vivo immunoglobulin isotype selection. Ann Rev Immunol 8: 303-333.

Gazzinelli RT, Oswald IP, Hieny S, James SL AND SHER A. 1992. The microbicidal activity of IFN$\gamma$ treated macrophages against Trypanosoma cruzi involves an L-arginine-dependent, nitrogen oxidemediated mechanism inhibitable by IL-10 and TGF$\beta$. Eur J Immunol 22: 2501-2506.

Hoft DF, Lynch RG AND KiRChHOFF LV. 1993. Kinetic analysis of antigen-specific immune responses in resistant and susceptible mice during infection with Trypanosoma cruzi. J Immunol 151: 7038-7047.

Hölscher C, Köhler G, Müller U, Mossmann H, Schaub GA and Brombacher F. 1998. Defective nitric oxide effector functions lead to extreme susceptibility of Trypanosoma cruzi-infected mice deficient in gamma interferon receptor or inducible nitric oxide synthase. Infect Immun 66: 1208-1215.

Lima MT, Jansen AM, Rondinelli E and Gattass CR. 1991. Trypanosoma cruzi: properties of a clone isolated from CL strain. Parasitol Res 77: 77-81.

Lima MT, LenZi HL and GatTass CR. 1995. Negative tissue parasitism in mice injected with a noninfective clone of Trypanosoma cruzi. Parasitol Res 81: 6-12.

Meyer-Zum-Büschenfelde C, Cramer S, TrumpFHEller C, Fleisher B AND Fro S. 1997. Trypanosoma cruzi induces strong IL-12 and IL-18 gene expression in vivo: correlation with interferongamma (IFN- $\gamma$ ) production. Clin Exp Immunol 110: 378-385.

Miller MJ, Wrightsman RA and Manning JE. 1996. Trypanosoma cruzi: protective immunity in mice immunized with paraflagellar rod proteins is associated with a T-helper type 1 response. Exp Parasitol 84: 156-167.

Paiva CN, Castelo-Branco MTL, Lannes-Vieira J AND GatTass CR. 1999. Trypanosoma cruzi: protective response of vaccinated mice is mediated by $\mathrm{CD}^{+}$cells, prevents signs of polyclonal T lymphocyte activation, and allows restoration of a resting immune state after challenge. Exp Parasitol 91:7-19.
Planelles L, Thomas MC, Alonso C and López MC. 2001. DNA immunization with Trypanosoma cruzi HSP70 fused to the KMP11 protein elicits a cytotoxic and humoral immune response against the antigen and leads to protection. Infect Immun 69: 6558-6563.

Pyrrho A, Moraes JlC, PeÇanha LMT and Gattass CR. 1998. Trypanosoma cruzi: IgG1 and IgG2b are the main immunoglobulins produced by vaccinated mice. Parasitol Res 84: 333-337.

REED SG. 1988. In vivo administration of recombinant IFN-gamma induces macrophage activation and prevents acute disease, immune suppression, and death in experimental Trypanosoma cruzi infections. J Immunol 140: 4342-4347.

Rodrigues MM, Ribeirão M, Pereira-Chioccola V, Renia L and Costa F. 1999. Predominance of CD4 Th1 and CD8 Tc1 cells revealed by characterization of the cellular immune response generated by immunization with a DNA vaccine containing a Trypanosoma cruzi gene. Infect Immun 67: 3855-3863.

Schnapp AR, EICKHOFF CS, Sizemore D, CurTiss R3 ${ }^{\text {RD }}$ AND Hoft DF. 2002. Cruzipain induces both mucosal and systemic protection against Trypanosoma cruzi in mice. Infect Immun 70: 5065-5074.

Soares MBP, Silva-Mota KN, Lima RS, Bellintani MC, DECARVAlHo LC P AND Ribeiro-Dos-SANTOS R. 2001. Modulation of chagasic cardiomyopathy by interleukin-4: dissociation between inflammation and tissue parasitism. Am J Pathol 159: 703-709.

Torrico F, Heremans H, Rivera MT, Van Marck E, Billiau A and Carlier Y. 1991. Endogenous IFN-gamma is required for resistance to acute Trypanosoma cruzi infection in mice. J Immunol 146: 3626-3632.

Zhang L AND TARLETON RL. 1996. Characterization of cytokine production in murine Trypanosoma cruzi infection by in situ immunocytochemistry: lack of association between susceptibility and type 2 cytokine production. Eur J Immunol 26: 102-109. 